
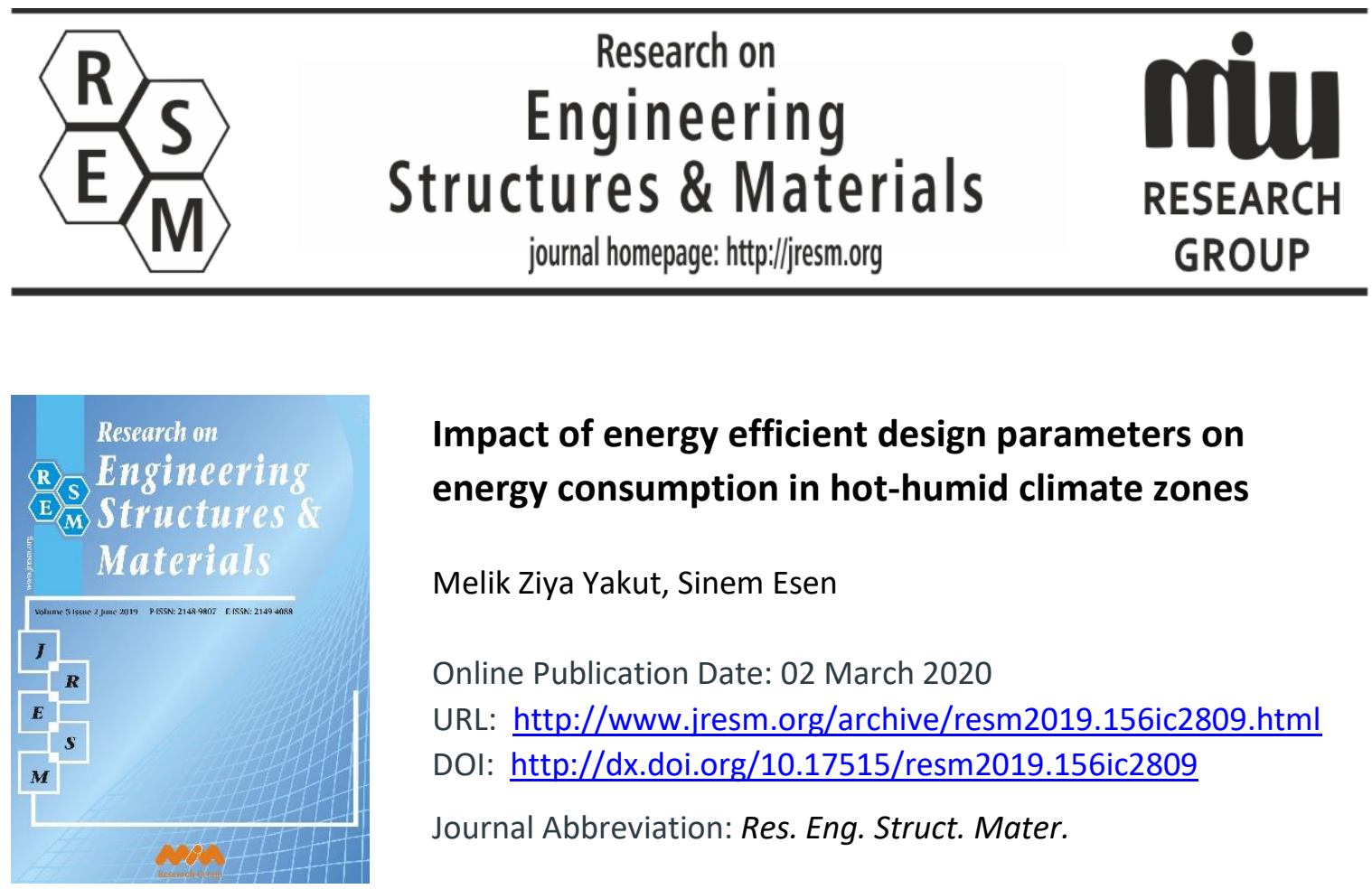

\title{
Impact of energy efficient design parameters on energy consumption in hot-humid climate zones
}

\author{
Melik Ziya Yakut, Sinem Esen \\ Online Publication Date: 02 March 2020 \\ URL: http://www.jresm.org/archive/resm2019.156ic2809.html \\ DOI: http://dx.doi.org/10.17515/resm2019.156ic2809 \\ Journal Abbreviation: Res. Eng. Struct. Mater.
}

\section{To cite this article}

Ziya Yakut M, Esen S. Impact of energy efficient design parameters on energy consumption in hot-humid climate zones. Res. Eng. Struct. Mater., 2020; 6(3): 197-206.

\section{Disclaimer}

All the opinions and statements expressed in the papers are on the responsibility of author(s) and are not to be regarded as those of the journal of Research on Engineering Structures and Materials (RESM) organization or related parties. The publishers make no warranty, explicit or implied, or make any representation with respect to the contents of any article will be complete or accurate or up to date. The accuracy of any instructions, equations, or other information should be independently verified. The publisher and related parties shall not be liable for any loss, actions, claims, proceedings, demand or costs or damages whatsoever or howsoever caused arising directly or indirectly in connection with use of the information given in the journal or related means.

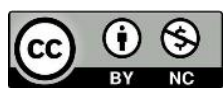
Published articles are freely available to users under the terms of Creative Commons Attribution - NonCommercial 4.0 International Public License, as currently displayed at here (the "CC BY - NC"). 


\title{
Research on Engineering Structures \& Materials
}

journal homepage: http://jresm.org

Research Article

\section{Impact of energy efficient design parameters on energy consumption in hot-humid climate zones}

\begin{abstract}
Melik Ziya Yakut ${ }^{* 1, a}$, Sinem Esen ${ }^{2, b}$
${ }^{1}$ Department of Mechatronics Engineering, Isparta University of Applied Sciences, Isparta, Turkey ${ }^{2}$ Department of Energy Systems Engineering, Isparta University of Applied Sciences, Isparta, Turkey

\begin{tabular}{|c|c|}
\hline e Info & Abstract \\
\hline & \multirow{14}{*}{$\begin{array}{l}\text { In this study; based on energy-efficient design parameters, the effects of building } \\
\text { design parameters on the energy consumption of the building were examined. } \\
\text { Accordingly, a reference building has been created as an example of application } \\
\text { in the hot-humid climate zone. In the process of modelling the building, BIM } \\
\text { (Building Information Modelling) software Autodesk Revit was used. The model } \\
\text { has been transferred to Green Building Studio (GBS) for energy performance } \\
\text { analysis and evaluation of design alternatives. The parameters evaluated in } \\
\text { terms of energy consumption of the building were selected from among the } \\
\text { design alternatives produced by GBS, based on energy-efficient design } \\
\text { parameters. As a result of the energy performance analysis of the reference } \\
\text { building via GBS, the building's annual electricity consumption is } 35,137 \mathrm{kWh} \\
\text { and the annual fuel consumption is } 93,729 \text { MJ. Based on the evaluation of } \\
\text { selected design parameters as a result of reference building energy performance } \\
\text { analysis; HVAC systems have been found to have the most impact on energy } \\
\text { consumption (rates of changes; } 36.83 \% \text { in annual electricity consumption, } \\
90.27 \% \text { in annual fuel consumption). HVAC systems, selected to be highly } \\
\text { efficient and suitable for climate type, have the potential to save significant } \\
\text { energy in the amount of energy consumption throughout the life cycle. In } \\
\text { addition to this, as of the early design phase, the energy efficient design of the } \\
\text { building is of great importance in terms of a holistic evaluation and maximum } \\
\text { energy efficiency. }\end{array}$} \\
\hline Received 28 Sep 2019 & \\
\hline & \\
\hline Revised 23 Jan 2020 & \\
\hline & \\
\hline Keywords: & \\
\hline Energy efficient & \\
\hline building; & \\
\hline & \\
\hline building design & \\
\hline parameters; & \\
\hline & \\
\hline BIM; BEM & \\
\hline & \\
\hline
\end{tabular}
\end{abstract}

(C) 2020 MIM Research Group. All rights reserved.

\section{Introduction}

Today, the growth in energy consumption has spread to all the main sectors of the economy and three quarters of the increase in energy demand is composed of industry and buildings. The building sector consumes $29 \%$ of the world's energy consumption [1]. The building sector, which has a substantial share in the increasing energy demand, uses a large rate of the total energy consumed as in the whole world in our country to provide user comfort in buildings. In the building sector, widespread use of energy efficient building design approach and renewable energy resource use is one of the most important issues. Unlike cars or electrical appliances -where the next generation can be more energy efficient than the previous one- buildings have decades of life [2]. For this purpose, the energy analysis process is being included in the design process with increasing regulations in the world. With the energy efficient design criteria to be implemented and the building standards aimed at increasing efficiency, the energy consumption of buildings can be reduced to low levels.

\footnotetext{
*Corresponding author: ziyayakut@isparta.edu.tr a orcid.org/0000-0003-4120-6016; b orcid.org/0000-0001-9725-977X DOI: http://dx.doi.org/10.17515/resm2019.156ic2809 
Energy efficient building design aims to reduce the carbon dioxide emission and provide energy saving by adapting the building to nature with passive strategies and supporting it with renewable energy sources. Energy efficiency building design can be achieved in two stages:

- Minimization of energy consumption rates by optimal application of energy efficient building design parameters,

- Integration of passive and active systems to increase the energy gain to the building.

In order to provide energy efficiency in buildings, the design should be made in a way that is compatible with local climate and geography. While the analysis in building designs is compatible with local environmental conditions, it is possible to use energy effectively with local material selection and passive and active systems integrated into the building. To achieve this goal, design parameters and energy-efficient analysis must be correctly determined. When these analyses are included in the design in the early design phase, energy savings are provided more and implementation costs are reduced to smaller amounts compared to the way they were involved in the later phases of the process.

Remain incapable of computer-aided design tools in some cases have led designers to choose BIM (Building Information Modelling) as an appropriate tool for integrating sustainability in the building sector as a holistic solution into their existing workflows [3]. BIM is specifically designed to support the application of energy analysis to identify possible energy gain or loss for the building, to demonstrate and predict their sustainability during the conceptual design phase [4]. BIM consists of the production and management process of all information corresponding to the building throughout the lifecycle, including the design and implementation phase. BIM software can increase the availability of whole building energy calculation through standard processes and parameters [5]. Among the benefits of incorporating design into the BIM process have included the following:

- To facilitate interdisciplinary (architect, engineer, designer, et al.) integrated work

- The ability to demonstrate the energy consumption trend of the building throughout its life cycle through energy performance analysis,

- Among the alternatives created based on energy performance analysis, the ability to identify alternatives and improvements that can keep the amount of energy consumption to a minimum throughout the lifecycle from the early design stage,

- The ability to easily create optimum design combinations in terms of energy efficiency and to make more effective decisions in the design process.

Through the software, many design alternatives and optimum combinations can be easily created to minimize the amount of energy consumption. The significance of BIM is to integrate the design process and the architectural life cycle of several information. Currently, model data of REVIT and other BIM software have been exported to various analysis software in GBXML format [6].

Another feature of BIM, BEM (Building Energy Modelling), integrates energy analysis with the design, construction, use and maintenance processes of buildings. This program, which deals with the building with a holistic approach, shows the user with quantitative data how effectively the designed building can use energy [7]. However, BEM has not yet fully benefited from the perpetual flow of information in digital modelling. For example, BEMrelated information must be manually re-entered into these tools, but this information has already been entered in BIM models [8]. Green Building Studio (GBS) is a web-based software that uses the DOE-2 engine for energy simulation, providing information on a building's energy consumption, carbon footprint, water consumption, material costs and matter such as. Green Building Studio can perform 3D modelling of building design states that affect energy simulation results [9]. 
Regarding the studies on the subject; the study of Abanda and Byers (2016) [10] has assessed the impact of orientation on energy consumption in small-scale structures and is evaluated how BIM can be used to simplify this process. In the GBS, different building orientations are tackled and the effects of all building energy are enquired. By virtue of an analysis of the energy consumption corresponding to different orientations, they observed that a well-guided structure could provide considerable energy savings over the life cycle. The aim of Kim et al. (2016) [11] is to perform energy analysis with a case study on a residence. With Autodesk Revit, BIMs are created for each scenario, and Green Building Studio is used to calculate the total energy load. The results are shown that if the windows are positioned at medium height in all directions, the building provides the minimum energy load and the positioning of the east window provides the maximum total energy load.

The study of Sorgato et al. (2016) [12] is to evaluate the effectiveness of window opening, ventilation control and building heat mass on energy consumption connected to the HVAC (Heating, Ventilation, and Air Conditioning) system in residences in Brazil. The results show that low thermal permeability and medium thermal capacity, energy consumption in cooling has decreased by $32 \%$. Mujeebu et al. (2016) [13] has presented a simulation study on the energy performance of a prototype office building in Saudi Arabia by changing the conventional polystyrene insulation and double-glazing with nano VIP (Vacuum Insulating Coating) and nano aerogel glazing. The building model was created in Autodesk Revit and the energy simulation was built by ECOTECT using Dhahran's weather data. The results show that nano VIP on the walls and roofs and nanogel windows together can maintain approximately $18 \%$ of the building's yearly energy consumption. Buratti et al. (2017) [14] is interested in the potential of high energy saving windows with a granular silica airgel to save energy in building renovations. Glass systems were examined taking account of two types of granular silica aerogel and several glass layers. Compared to traditional windows, $63 \%$ reduction in $U$-value and a 30\% reduction in light transmittance were achieved.

Chel and Kaushik (2017) [15] present solutions and recommendations on renewable energy technologies and energy efficient building development for sustainability. Firstly, they pointed out that proper design of daylight would result in a great reduction in the use of artificial lights while daylight hours, thus reducing energy consumption for lighting. The second is to use low embodied energy building materials for building construction. Third, it's relevant operational energy savings by using energy-efficient equipment in the building. The latter relates to the use of added renewable systems for hot water heating, solar PV electrification and the like. Sahin Çağlı (2018) [16] worked on improving the design of two multi-storey housing projects with dynamic energy simulation and achieving energy efficiency in the hot climate zone of Adana. According to the environmental building shading calculations, the cooling load was reduced from $95.000 \mathrm{kWh}$ to $78.751 \mathrm{kWh}$, with an energy saving of approximately $17 \%$, with orientation, selection of optimal building components and insulation materials, and minimization of transparent areas. Gonzalo et al. (2019) [17], in their work, intended to develop an effective and repeatable testing method to assess the impact of various on the energy performance and comfort requirements of buildings. After removing all geometric and spatial information of the building from the BIM model, an energy simulation was made using Energy Plus. They found that controlling the natural ventilation ratio could help to decrease $45 \%$ of heating and cooling energy consumption in winter.

The aim of this study is to examine the effects of building design parameters determined starting from energy-efficient design parameters on the energy consumption of the building. In this way, the design parameters that prominent in minimizing the energy consumption of the building will be revealed. Distinctly from the literature studies examined in this study, It is aimed to evaluate the design parameters that are thought to 
affect the energy performance in GBS, which is the BEM software which stands out day by day in the energy performance analysis. In this way, it will be specified how GBS handles the energy performance analysis process. At the same time, it is the study of the effects of the specified parameters on energy consumption through GBS. In addition to this, the importance of designing the building with an energy efficient design approach from the early design stage will be emphasized.

\section{Methodology}

Energy-efficient design parameters are divided into three parameters for the user, the external environment and the building. Energy-efficient systems are divided into passive and active systems. Accordingly, a reference building was established as an example of application in the hot-humid climate zone so as to demonstrate the effect of energyefficient design parameters on energy consumption. The reference building was designed to meet a building's energy requirements at a minimum in terms of the type of climate in which it is located. The parameters considered when creating the reference building are shown in Figure 1.

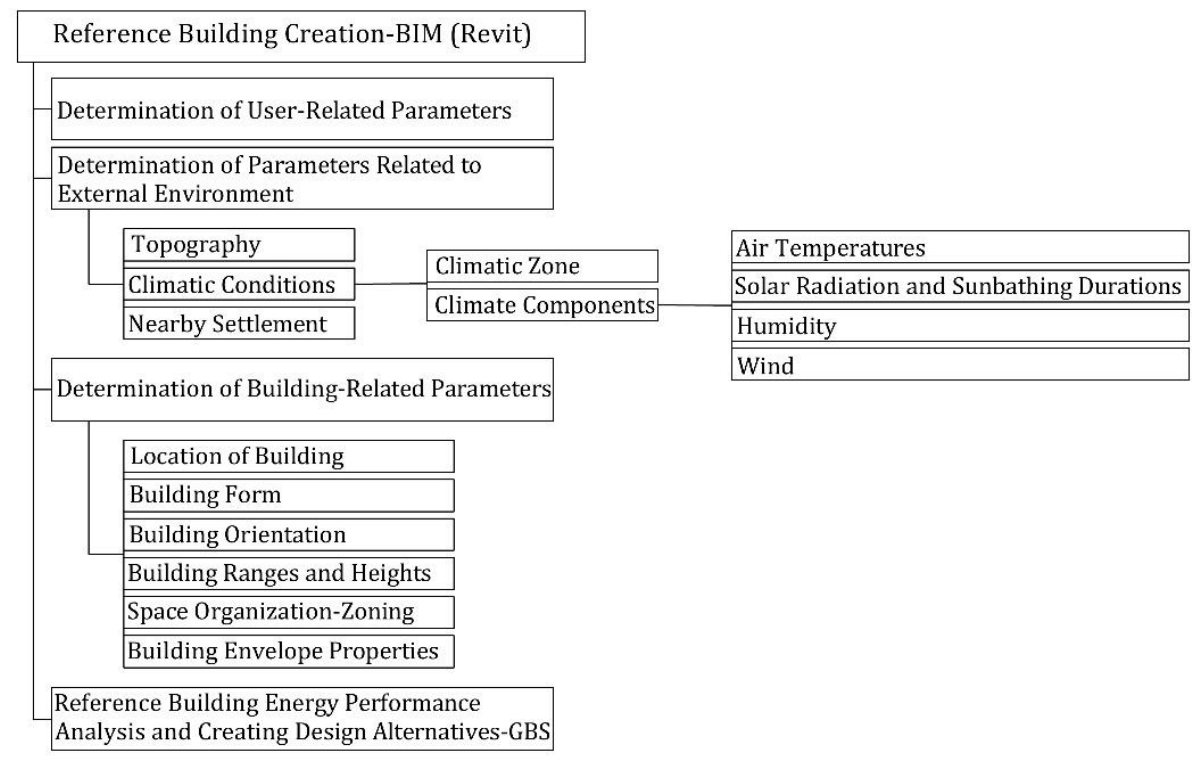

Fig. 1 The flow chart of the creation of the reference building

The reference building is located in a hypothetical topography in Antalya province, which is in the hot-humid climate zone. In this type of climate, the consumption of cooling energy is more important than the consumption of heating energy. It was acted on by accepting that the building, which was located in a field exposed to intense solar radiation throughout the year, was not shaded by other buildings or obstacles. Project details and monthly temperature chart are shown in Figure 2. 

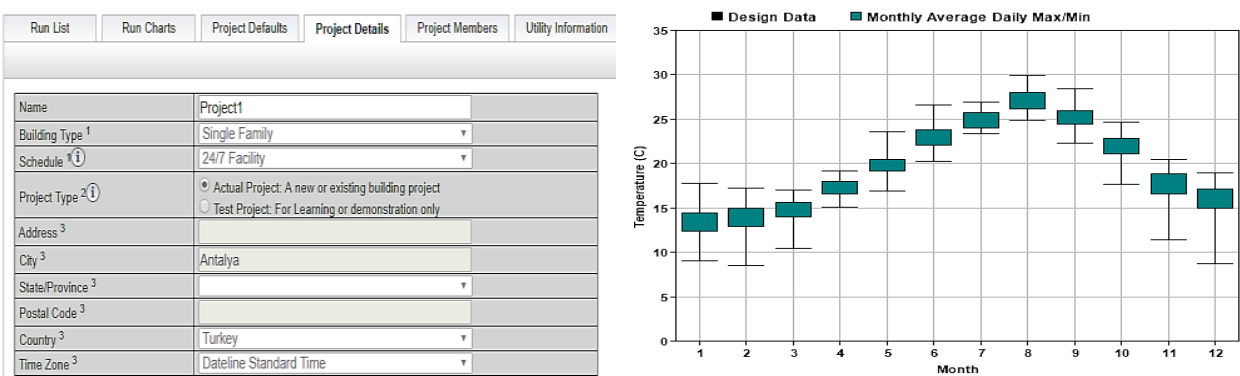

Fig. 2 Project details and monthly temperature chart

The building is located on the top of the land in order to provide maximum benefit from wind effects, reduce the negative effects of humidity and provide sun protection for hothumid climate type. It is designed as a detached house with a ground floor and a normal floor. The building form is designed in a rectangular form with low depth and long facades to get maximum benefit from the prevailing wind. At the same time, the long facade and living areas of the building are directed to the north (Fig. 3).

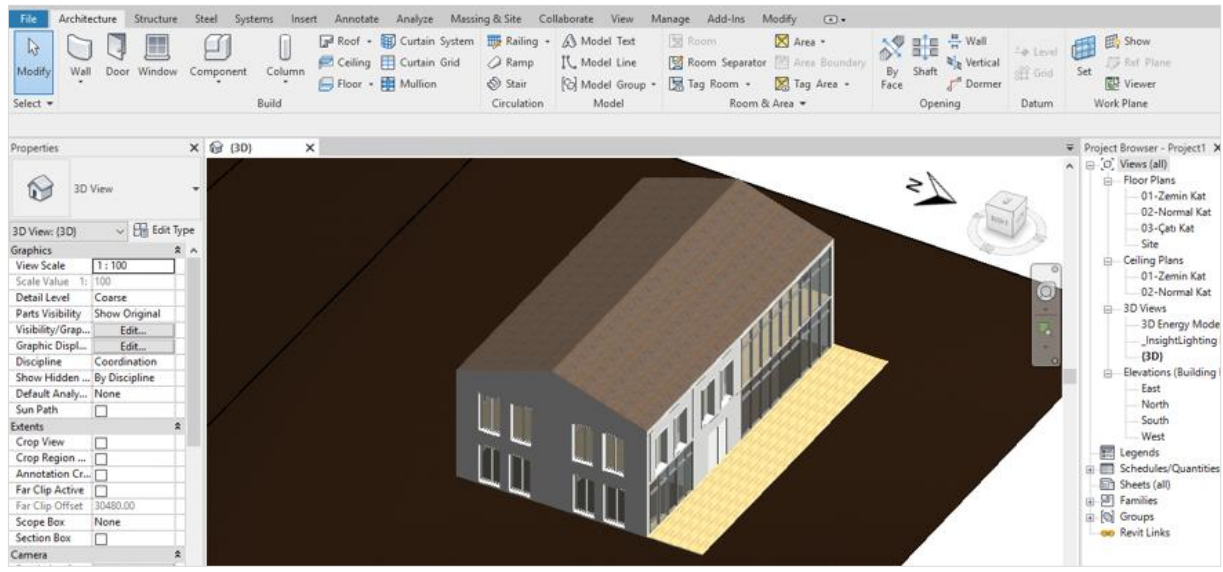

Fig. 3 3D view of the reference building in Revit

The reference building heating system is central hot water system and fuel type natural gas, cooling system is determined as split air conditioning. The WWR (Window-to-Wall Ratio) in the building is $65 \%$ of the north facade, $25 \%$ of the south facade, $32 \%$ of the eastern facade and $28 \%$ of the western facade. When determining the thermophysical properties of the opaque and transparent components of the reference building, the requirements of the hot-humid climate type, were taken into consideration. The U values (heat transfer coefficients) of the reference building envelope components are shown in Table 1. 
Table 1. $\mathrm{U}$ values of reference building envelope components $\left(\mathrm{W} / \mathrm{m}^{2} \mathrm{~K}\right)$

\begin{tabular}{cc}
\hline & U Values \\
& $\left(\mathrm{W} / \mathrm{m}^{2} \mathrm{~K}\right)$ \\
\hline Exterior Wall & 0,47 \\
Roof & 0,33 \\
Floor & 0,46 \\
Window & 2,4 \\
\hline
\end{tabular}

Different alternatives of parameters affecting the energy performance of the building were evaluated. In the process of modelling the building, BIM software Autodesk Revit was used. The model was transferred to GBS for the energy performance analysis and evaluation of design alternatives. GBS is one of Revit's web-based energy modelling software. The parameters evaluated in terms of energy consumption of the building were selected from among the design alternatives produced by GBS based on energy-efficient design parameters. While making these elections, were acted with program restrictions. The selected parameters include the following:

- The orientation of the building

- HVAC systems

- Lighting control

- Roof insulation

- Wall insulation

- WWR, Glass type, Sun control.

\section{Results and Discussion}

As a result of the energy performance analysis of the reference building through GBS, the building annual electricity consumption is $35,137 \mathrm{kWh}$ and the annual fuel consumption is 93,729 MJ (Fig. 4). GBS via was created different design alternatives that have different effects on energy consumption for the reference building. Fig. 5 is shown part of the interface listing design alternatives created by GBS

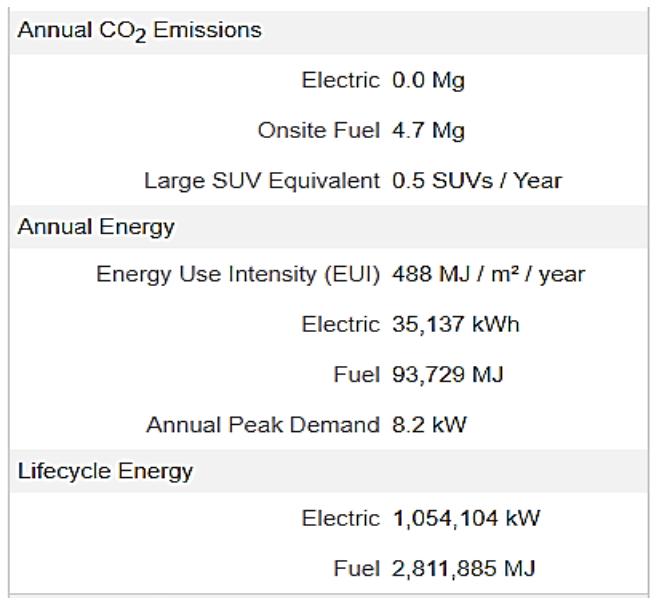

Fig. 4 Reference building annual energy performance summary 


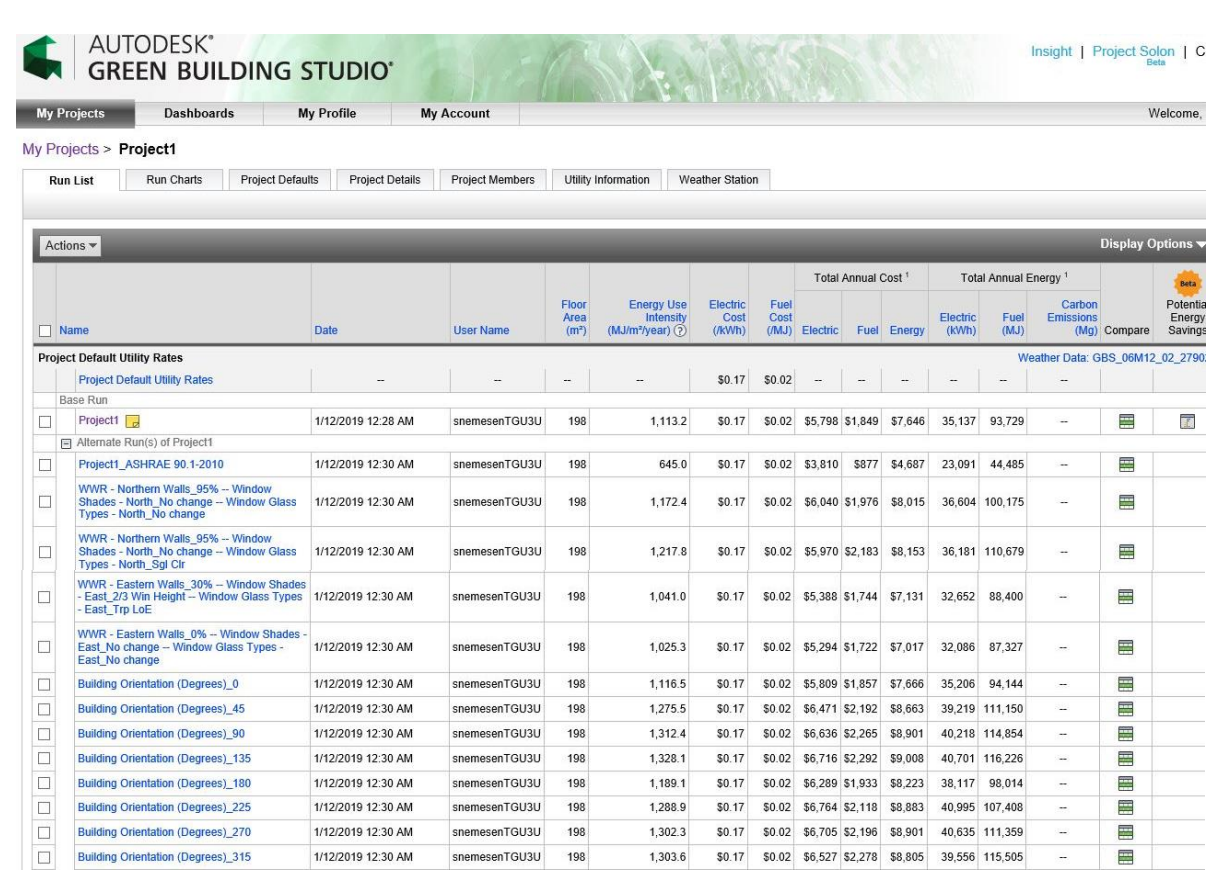

Fig. 5 Part of the interface listing design alternatives created by GBS

Numerous alternatives have been created through software for parameters such as the orientation of the building, HVAC systems, lighting control, roof insulation, wall insulation, WWR, glass type, sun control. The software evaluated each parameter within its own possibilities. For example, the effect of 360 degree orientation possibilities on energy performance for the orientation of the building has been revealed through software. Alternatives that affect energy performance to a minimum and maximum based on the possibilities of each determined parameter have been evaluated. The selected parameters and the alternatives of these parameters that minimize and maximize energy consumption are as follows:

- The orientation of the building; for minimum energy consumption " 0 ", for maximum energy consumption " $120^{\circ}$ "

- HVAC systems; for minimum energy consumption "Residential 17 SEER/9.6 HSPF Split HP $<5.5$ ton", for maximum energy consumption "VAV, COP 3.5 Low Efficiency Chiller, 65\% Eff. Gas Boiler, no economizer"

- Lighting control; for minimum energy consumption "Daylighting Controls", for maximum energy consumption "No change"

- Roof insulation; for minimum energy consumption "Wood Frame Roof with Insulation", for maximum energy consumption "Wood Frame Roof without Insulation"

- Wall insulation; for minimum energy consumption "Cavity Wall with Insulation", for maximum energy consumption "Metal Frame Wall without Insulation"

- WWR, Glass type, Sun control; for minimum energy consumption "WWR-Southern Walls_65\%, Window Glass Types-South_Trp L, Window Shades-South_1/3 Win Height", for maximum energy consumption "WWR-Southern Walls_95\%, Window Glass Types-South_Sgl Clr, Window Shades-South_No change". 
As a result of the reference building energy performance analysis, among the design parameters created by GBS, annual minimum and maximum energy consumptions of the selected design parameters according to the method, and the rates of change according to the reference building energy consumption are shown in Table 2.

Table 2. Annual minimum and maximum energy consumption of design parameters in hot-humid climate zone according to method, and rates of change according to reference building energy consumption

\begin{tabular}{|c|c|c|c|c|c|c|c|c|}
\hline \multirow[t]{3}{*}{$\begin{array}{c}\text { Reference } \\
\text { Building } \\
\end{array}$} & \multicolumn{3}{|c|}{$\begin{array}{l}\text { Electricity Consumption } \\
(\mathrm{kWh})\end{array}$} & 35,137 & \multicolumn{4}{|c|}{ Fuel Consumption (MJ) 93,729 } \\
\hline & \multicolumn{4}{|c|}{ Minimum Consumption } & \multicolumn{4}{|c|}{ Maximum Consumption } \\
\hline & $\begin{array}{c}\text { Electricity } \\
\text { Consump- } \\
\text { tion } \\
(\mathrm{kWh})\end{array}$ & $\begin{array}{c}\text { Rate of } \\
\text { Change } \\
(\%)\end{array}$ & $\begin{array}{c}\text { Fuel } \\
\text { Consump } \\
\text { tion } \\
(\mathrm{MJ})\end{array}$ & $\begin{array}{l}\text { Rate of } \\
\text { Chang } \\
\text { e (\%) }\end{array}$ & $\begin{array}{c}\text { Electricity } \\
\text { Consumpt } \\
\text {-ion } \\
(\mathrm{kWh})\end{array}$ & $\begin{array}{c}\text { Rate of } \\
\text { Change } \\
(\%)\end{array}$ & $\begin{array}{c}\text { Fuel } \\
\text { Consumpt } \\
\text {-ion } \\
\text { (MJ) }\end{array}$ & $\begin{array}{c}\text { Rate of } \\
\text { Change } \\
(\%)\end{array}$ \\
\hline $\begin{array}{c}\text { The } \\
\text { Orientation } \\
\text { of the } \\
\text { Building }\end{array}$ & 35,137 & - & 93,729 & - & 40,972 & -16.6 & 118,104 & -26 \\
\hline $\begin{array}{c}\text { HVAC } \\
\text { Systems }\end{array}$ & 22,195 & +36.8 & 9,114 & +90.2 & 60,001 & -70.7 & 116,633 & -24.4 \\
\hline $\begin{array}{l}\text { Lighting } \\
\text { Control }\end{array}$ & 34,206 & +2.6 & 94,905 & -1.2 & 35,206 & -0.2 & 94,144 & -0.4 \\
\hline $\begin{array}{c}\text { Roof } \\
\text { Insulation } \\
\end{array}$ & 35,137 & - & 93,729 & - & 35,350 & -0.6 & 94,250 & -0.5 \\
\hline $\begin{array}{c}\text { Wall } \\
\text { Insulation } \\
\end{array}$ & 35,137 & - & 93,729 & - & 36,890 & -5 & 120,808 & -28.9 \\
\hline WWR, Glass & & & & & & & & \\
\hline $\begin{array}{c}\text { Type, Sun } \\
\text { Control }\end{array}$ & 32,366 & 7.8 & 83,831 & 10.5 & 48,402 & -37.7 & 132,810 & -41.6 \\
\hline
\end{tabular}

The reference building is located in a hot-humid climate zone and the design parameters are selected to provide minimum optimization in a holistic way. Numerous alternatives are created by GBS on parametrical basis, which have close results with the consumption amounts in the table. The minimum consumption amounts in the orientation of the building, roof and wall insulation parameters were provided by the choices made when creating the reference building. Therefore, the rate of change according to the reference building is not given. However, the rates of change in maximum consumption are indicated in the table. In the lighting control parameter, while the minimum electricity consumption is achieved, fuel consumption increases slightly. This is due to a slight increase in fuel use to compensate for the heat lost from lighting equipment as a result of efficient use. The most positive change was in HVAC systems (rates of changes; $36.83 \%$ in annual electricity consumption, $90.27 \%$ in annual fuel consumption). This was followed by WWR, glass type, solar control parameter (rates of changes; $7.88 \%$ in annual electricity consumption, $10.56 \%$ in annual fuel consumption). The general characteristic of the parameters in the table, which leads to positive changes in energy consumptions, is that they are highly efficient and climate-appropriate choices. Evaluating parameters with a holistic and energy efficient approach as from the design stage will provide maximum energy savings. 


\section{Conclusions}

In this study, the effects of building design parameters determined based on energy efficient design parameters on energy consumption of the building were examined. Accordingly, the importance of designing the building with an energy efficient design approach from the early design stage is emphasized. The parameters that were evaluated in terms of energy consumption of the building were selected among the design alternatives produced by GBS based on energy efficient design parameters. The selection process was carried out in compliance with program constraints. The design parameters selected as a result of the reference building energy performance analysis were evaluated (annual electricity consumption 35,137 kWh, annual fuel consumption 93,729 MJ). The results of the study include the following:

- In this respect, it is determined that HVAC systems have the most effect on energy consumption (rates of changes; $36.83 \%$ in annual electricity consumption, $90.27 \%$ in annual fuel consumption). This is due to the fact that HVAC systems are selected high efficiency and suitable for climate type.

- It is emphasized that energy-efficient choices have the potential to save significant energy in the amount of energy consumption throughout the life cycle.

- In addition to this, from the early design stage, it has been observed that the holistic energy-efficient design of the building is of great importance in terms of maximum energy efficiency.

- It has experienced that the inclusion of BIM in the design process shortens the energy performance analysis process, which requires considerable effort. Through the software, many design alternatives and optimum combinations can be easily created to minimize the amount of energy consumption.

Considering that the growing energy needs in the face of the rapidly growing world population and sectoral structures are still primarily supplied by fossil fuels, the importance of these solution methods is increasing. At the same time, there is depletion of fuel reserves in the near future, and their use as energy source is increasing the emission values of greenhouse gases such as $\mathrm{CO}_{2}$ in the atmosphere, resulting in global warming and climate change. For these reasons, the construction sector, which has a large share in global energy consumption, should adopt an energy efficient design approach from the early design stage. Furthermore, the use of renewable energy sources should be taken into account in the design. The researches and developments on this subject will contribute to the increase of knowledge on the subject.

\section{References}

[1] BP Energy. BP Energy Outlook 2019 Edition, 29, 2019.

[2] Turk Ž, Klinc R, Ma Z. Towards a Parsimonious Information Management for Energy Retrofitting of Buildings. Proceedings of the Creative Construction Conference, Budapest, Hungary, 490 - 495, 2019. https://doi.org/10.3311/CCC2019-067

[3] Khoshdelnezamiha G, Liew SC, Bong VNS, Ong DEL. BIM-based Approach for Green Buildings in Malaysia. Earth and Environmental Science, 2018;268(2019):1-8. https://doi.org/10.1088/1755-1315/268/1/012052

[4] Ebrahim A, Wayal AS, Cook M. BIM Based Building Performance Analysis Of A Green Office Building. International Journal Of Scientific \& Technology Research, 2019;8(08):566-573.

[5] Lu Y, Wu Z, Chang R, Lİ Y. Building Information Modeling (BIM) for green buildings: A critical review and future directions. Automation in Construction, 2017;83(2017):134148. https://doi.org/10.1016/j.autcon.2017.08.024 
[6] Xu G, He Y. Research on Decoration Design of Green Building Based on BIM Technology. Earth and Environmental Science, 2019;242(2019):1-7. https://doi.org/10.1088/1755-1315/242/6/062073

[7] Gerrish K, Ruikar K, Cook M. Using BIM Capabilities to İmprove Existing Building Energy Modelling Practices. Engineering, Construction and Architectural Management, 2017;24(2):190-208. https://doi.org/10.1108/ECAM-11-2015-0181

[8] Gao H, Koch C, Yupeng W. Building information modelling based building energy modelling: A review. Applied Energy, 2019;238(2019):320-343. https://doi.org/10.1016/j.apenergy.2019.01.032

[9] Kim JU, Hadadi OA, Kim H, Kim J. Development of A BIM-Based Maintenance DecisionMaking Framework for the Optimization between Energy Efficiency and Investment Costs. Sustainability, 2018;10:1-15. https://doi.org/10.3390/su10072480

[10] Abanda FH, Byers L. An İnvestigation of the Impact of Building Orientation on Energy Consumption in A Domestic Building Using Emerging BIM(Building İnformation Modelling). Energy, 2016;97:517-527. https://doi.org/10.1016/j.energy.2015.12.135

[11] Kim S, Zadeh PA, Staub-French S, Froese T, Terim Cavka B. Assessment of the Impact of Window Size, Position and Orientation on Building Energy Load Using BIM. Procedia Engineering, 2016;145:1424-1431. https://doi.org/10.1016/j.proeng.2016.04.179

[12] Sorgato MJ, Melo AP, Lamberts R. The Effect of Window Opening Ventilation Control on Residential Building Energy Consumption. Energy and Buildings, 2016;133:1-13. https://doi.org/10.1016/j.enbuild.2016.09.059

[13] Mujeebu MA, Ashraf N, Alsuwayigh AH. Effect of Nano Vacuum Insulation Panel And Nanogel Glazing on The Energy Performance of Office Building. Applied Energy, 2016; 173:141-151. https://doi.org/10.1016/i.apenergy.2016.04.014

[14] Buratti C, Moretti E, Zinzi M. High Energy-Efficient Windows with Silica Aerogel for Building Refurbishment: Experimental Characterization and Preliminary Simulations in Different Climate Conditions. Buildings, 2017;7(8):1-12. https://doi.org/10.3390/buildings7010008

[15] Chel A, Kaushik G. Renewable Energy Technologies for Sustainable Development of Energy Efficient Building. Alexandria Engineering Journal, 2017:1 - 15.

[16] Çağlı Şahin Z. Enerji Etkin Bina Tasarımı ve Adana Örneği, PhD Thesis, Çukurova University, Adana, Turkey, 149 - 152, 2018.

[17] Gonzalo FDA, Ferrandiz JA, Moreno B. Building Energy Modeling by means of BIM Software. A Case Study with Water Flow Glazing. 7th European Conference On Renewable Energy Systems, Madrid, Spain, 1 - 10, 2019. 